ISSN 0975-3311

Ushus JBMgt, 9, 1 (2010) 1-10

ISSN 0975-3311 | https://doi.org/10.12725/ujbm.16.1

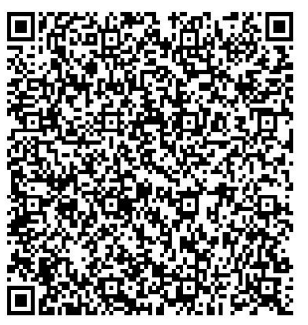

\title{
A STUDY ON JOB MOTIVATION OF EMPLOYEES IN THANJAVUR SPINNING MILL LTD., THANJAVUR
}

Sangeetha Senthil*
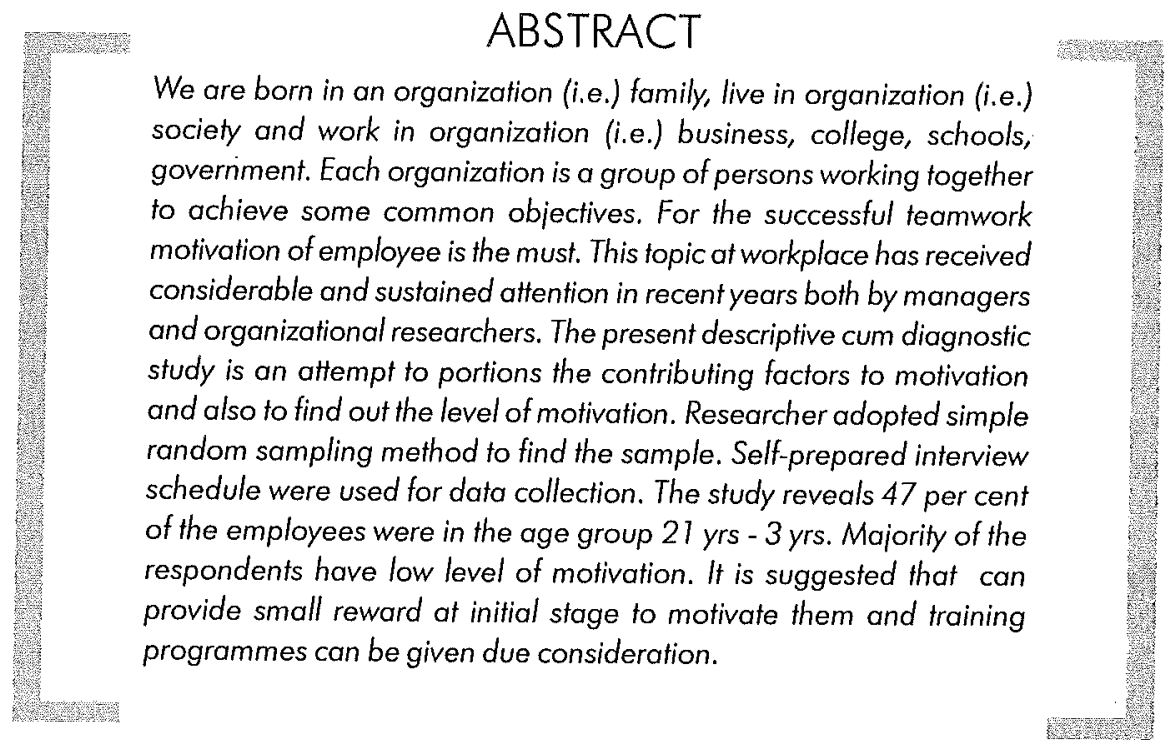

* Dept. of Social Work, Bon Secours College for Women, Vilar Bypass Road, Thanjavur-6, T.Nadu. 


\section{Introduction}

\section{Motivation}

"We can take a horse to water, but cannot make it to drink"

The concept of motivation is extremely important for the understanding of individual and organization behaviour and efficiency. Motivation is a common concept covering all factors of production that initiate, direct and organize the behaviour of the individual and determine the intensity, propensity and persistence of that behaviour. It is a very complex and fluid concept influenced by great many broader social, organizational and individual factors.

Man should be motivated to carryout plans, policies, and programs etc., laid down by organization for utilizing the other resources to the best of their efforts. In other words, utilization of resources is not possible to their fullest extent unless man is induced to contribute his efforts towards attaining the organizational goals. All the members in the organizations try to put their efforts to achieve the objectives of the organization. The introduction of motivational plans reduces the major labour problems such as labour turn-over, absenteeism, indiscipline, grievances etc., and motivates them to contribute to the maximum. For the successful team work, motivation of the employee is the must, motivation plays an importable role in any organization as organizational behavior is complete in nature. The topic of motivation at work has received considerable and sustained attention in recent years among both practicing managers and organizational researchers. Man alone can produce through motivation, creativity an output greater than the sum of his inputs. Motivation is derived from the word "motive" means any idea, need, emotion or organic state prompts a man to an action. Motive is an internal factor that integrates a man's behavior. As the motive is within the individual, it is necessary to study needs, emotions, etc., in order to motivate him to work.

\section{Motivation has been defined as,}

- According to William Scot, motivation means "A process of stimulating people to action to accomplish desired goals". 
The purpose of this study was to describe factors in motivating employees at Thanjavur Spinning Mills, Thanjavur. This study is the attempt made by the researcher, to find out the factors responsible for motivation and level of motivation among the employees of Thanjavur Spinning Mills Ltd., Thanjavur and how its improves the productivity.

\section{Review of Literature}

- Ganguly (1954) conducted a study in an Indian Railway Workshop and found that three most highly ranked motivational factors are adequate salary, job security are opportunity for promotion. The exact nature of work done, the magnitude of responsibility assigned to workers and appreciation of work done by others were found to be items, of relatively low importance. The nature of supervision was ranked fifth where as the incentive value of medical and health insurance, housing, subsidized canteen and fringe benefits was difficult evaluate.

- Rao and Ganapathi (1973) conducted a study on the motivational pattern of highly skilled and skilled workers in the pattern of Herzberg's model and found that motivation and hygiene factors contributed to the satisfaction or dissatisfaction of either of the occupational group.

- Kovach (1987) a study of industrial employees was conducted which yielded the following ranked order of motivational factors : (a) interesting work, (b) full appreciation of work done, and (c) feeling of being in on things. Another study of employees.

- Smith (1994) Motivated employees are needed in our rapidly changing workplaces. Motivated employees help organizations survive. Motivated employees are more productive. To be effective, managers need to understand what motivates employees within the context of the roles they perform. Of all the functions a manager performs, motivating employees is arguably the most complex.

- According to Dr. N. Pancharathan (1999) in his study. "Love an the HR Tool" quoted from the ancient works of Tamil poet Thiruvalluvar feels that human trait of love and compassion ought to be the essential ingredient of workable to strategy. 


\section{Research Methodology}

\section{Research Design}

The researcher has attempted to find out the various socio-demographic characteristic of the respondents and to describe their association with various dimensions of the study. The study is mainly or mend to get better understanding of the existing level of motivation in Thanjavur Spinning Mills Ltd., therefore had adopted descriptive cum diagnostic research design.

\section{Aims an Objectives}

- To study the socio-demographic factors of the respondents.

- To study the level of motivation of the employees at Thanjavur Spinning Mills Ltd., Thanjavur.

- To find out the motivation with selected socio-economic variables like years of experience, age, salary etc.,

- To suggest suitable measures for improving job motivation of the employees.

\section{Reseachch Hypothesis}

- There is association between salary and job motivation.

- There is association between age and job motivation.

- There is association between experience and job motivation.

- There is association between sex and job motivation.

\section{Limitation of the Study}

- This research is limited only to the employees of Thanjavur Spinning Mills Ltd.,

- The study is based on the data imparted by the respondents which may be biased.

- Time constraint was the major limitation. 


\section{Analysis and Interpretation}

\section{Introduction}

This chapter deals with the analysis and interpretation of data. The researcher used coding, tabulation and diagrams for analysis. The research analyzed variable such as age, sex, salary, departments, work experience.

Distribution of Respondents by Age

\begin{tabular}{|c|l|c|c|}
\hline S. No. & Age & $\begin{array}{c}\text { No. of Respondents } \\
(\mathbf{n}: 100)\end{array}$ & Percentage(\%) \\
\hline 1. & Below 20 years & 38 & 38.0 \\
2. & 21 to 30 years & 47 & 47.0 \\
3. & 31 to 40 years & 14 & 14.0 \\
4. & 41 to 50 years & 1 & 1.0 \\
\hline & TOTAL & 100 & 100.0 \\
\hline
\end{tabular}

From the above table : 1 it is observed that 47 per cent of the respondents belongs to age group between 21 yrs to $30 \mathrm{yrs}, 38$ per cent of the respondents are from age group below $20 \mathrm{yrs}, 14$ per cent of the respondents belongs to age group 31 yrs to $40 \mathrm{yrs}$ and very small percentage of respondents (i.e.) 1 per cent of the respondents belongs to age group between 41 yrs to 51 yrs.

It is clear that majority of the employee were young years of age in this organization.

Distribution of Respondents by Sex

\begin{tabular}{|c|l|c|c|}
\hline S. No. & Sex & $\begin{array}{c}\text { No. of Respondents } \\
(\mathrm{n}: 100)\end{array}$ & Percentage(\%) \\
\hline 1. & Male & 39 & 39.0 \\
2. & Female & 61 & 61.0 \\
\hline & TOTAL & 100 & 100.0 \\
\hline
\end{tabular}

Above table : 2 states that more than half of the respondents (61\%) are females and only 39 per cent of the respondents are male. 
It is significant to notice that majority of the employees in Thanjavur Spinning Mills were women employees.

Distribution of Respondents by Level of Job Motivation

\begin{tabular}{|c|l|c|c|}
\hline S. No. & $\begin{array}{l}\text { Level of Job } \\
\text { Motivation }\end{array}$ & $\begin{array}{c}\text { No. of Respondents } \\
(\mathbf{n}: 100)\end{array}$ & Percentage(\%) \\
\hline 1. & Low & 57 & 57.0 \\
2. & High & 43 & 43.0 \\
\hline \multicolumn{2}{|c|}{ TOTAL } & 100 & 100.0 \\
\hline
\end{tabular}

From the above table, it is inferred that 57 per cent of the respondents shows low level of motivation, 43 per cent of the respondents shows high level of motivation.

It clearly indicates that majority of respondents have low level of motivations.

Training Programme as Factor for Motivation

\begin{tabular}{|c|l|c|c|}
\hline S. No. & Particulars & $\begin{array}{c}\text { No. of Respondents } \\
(\mathbf{n}: 100)\end{array}$ & Percentage(\%) \\
\hline 1. & Yes & 92 & 92.0 \\
2. & No & 8 & 8.0 \\
\hline \multicolumn{2}{|c|}{ TOTAL } & 100 & 100.0 \\
\hline
\end{tabular}

The above table indicates that among 100 respondents 90 per cent of them showed positive response towards the statement training programme as factor for motivation, 10 per cent have shown negative response. This clearly indicates that majority of the respondents think training as a motivational factor. 
$\mathrm{H}-4$

' $f$ ' Test between Male and Female Respondents with Regard to their Job Motivation

\begin{tabular}{|c|l|c|c|c|}
\hline S. No. & Variable & $\begin{array}{c}\bar{X} \\
(\mathbf{n}: 100)\end{array}$ & S.D. & $\begin{array}{c}\text { Statistical } \\
\text { Inference }\end{array}$ \\
\hline 1. & Male & 19.92 & 2.89 & $\mathrm{t}=-0.112$ \\
& Female & 20.00 & 3.63 & $\begin{array}{c}\mathrm{df}=98 \\
\mathrm{P}>0.05 \\
\end{array}$ \\
& & & & Not Significant \\
\hline
\end{tabular}

The above table insists there is no significant relationship between the sex and job motivation of the respondents.

Therefore we reject the hypothesis (i.e.) there is relationship between sex of the respondents and job motivation and accept the alternate hypothesis.

\section{$\mathrm{H}-1$}

One Way Analysis of Variance among Salary of the Respondents with Regard to their Job Motivation

\begin{tabular}{|c|l|c|c|c|c|c|}
\hline S.No. & Source & $\mathrm{df}$ & SS & $M S$ & $\bar{X}$ & $\begin{array}{c}\text { Statistical } \\
\text { Inference }\end{array}$ \\
\hline 1. & Job Motivation & & & & & \\
& Between Groups & 2 & 0.245 & .123 & $\mathrm{G} 1=1.44$ & $\mathrm{~F}=.490$ \\
& Within Groups & 97 & 24.265 & .250 & $\mathrm{G} 2=1.33$ & $\mathrm{P}>0.05$ \\
\hline & Total & 99 & 24.510 & & $\mathrm{G} 3=1.50$ & Not Significant \\
\hline
\end{tabular}

$\mathrm{G} 1=$ Below Rs. $3000 \quad \mathrm{G} 2=$ Rs. 3001 to $4000 \quad$ G3=Above Rs. 5000

From the above table it is found that there is no significant difference among salary and job motivation of the respondent.

Therefore we accept the hypothesis (i.e.) there is relationship between salary and job motivation. 
$\mathrm{H}-4$

Association between Sex of the Respondents and the Level of Job Motivation

\begin{tabular}{|l|l|c|c|c|}
\hline \multirow{2}{*}{ S. No. } & \multirow{2}{*}{ Sex } & \multicolumn{2}{|c|}{ Sex } & $\begin{array}{c}\text { Statistical } \\
\text { Inference }\end{array}$ \\
\cline { 3 - 4 } & & Low (n:57) & High (n:43) & \\
\hline 1. & Male & 24 & 15 & $X^{2}=0.537$ \\
& Female & 33 & 28 & $\begin{array}{c}\mathrm{df}=1 \\
\mathrm{P}>0.05 \\
\end{array}$ \\
& & & & Not Significant \\
\hline
\end{tabular}

The above table indicates that there is no significant association between sex and job motivation.

Therefore we reject the hypothesis (i.e.) association between sex of the respondents and job motivation and accept the alternate hypothesis.

\section{Major Findings}

- Majority of the respondents belongs to the age group between 21 yrs to 30 yrs.

- It was significant to find that majority of employees at Thanjavur Spinning Mill were women.

- Majority of the respondents were getting the salary below Rs. 3000/-

- 33 per cent of the respondents were working in Spinning department.

- Majority of respondents 65 per cent of the respondents have work experience below 5 yrs.

- Majority of the respondents have low level of motivation.

- Among 100 respondents 89 per cent of them have shown positive response towards the statement "work place is orderly well and it is not burden to work".

- 85 per cent of the respondents agreed with the statement that jobs helps in bringing out various talents. 
- 76 per cent of the respondents feels that promotion should be based on ability of the workers.

- 92 per cent of the respondents feel training programme as motivational factor.

- From chi-square test, it is found that there is no relationship between sex and motivation.

- Through one-way analysis of variance, it is found that there is no significant difference among the work experience and job motivation.

- It is found that there is high association between the age of the respondent and job motivation.

- There is no significant association between various department and levels of job motivation.

- It is found that there is no significant relationship between work experience and jobs motivation.

\section{Suggestions}

The researcher felt that the following suggestions would be considered to increase motivational level among the employees of Thanjavur Spinning Mill Ltd., Thnajavur.

- The management can provide small reward at the initial stage, boon for the employees and give recognition for their performance.

- The management should consult the employees while framing further rules and regulation.

- The company can take the initiative to conduct game way method of motivating the employees and also increase their efficiency.

- The fringe benefits provided by the company motivates the employee to a great extent, company have to take necessary step to provide fringe benefits to employees.

- Suggestion box can be kept at various place inside the working area, so that employees will share their, ideas regarding the methods to motivate employees. 
- Training programme can be conducted every now and then to improve the quality of work which in turn raise the level the motivation.

- Promotion should be based on ability rather than seniority.

\section{Conclusion}

Motivation is one of the important factor affecting human behavior. The level of motivation does not only affect perception and learning but also affect the performance of employees. Apart from salary, there are many other factors which play important role in motivating the employees. Therefore certain suggestion are given which may be considered by management to motivate their employees. Thus the priceless, value of men and there lies the need of motivating them.

\section{References}

MAMORIA C.B. 2002. "Personnel Management", Mumbai, Holno, Himalaya Publications.

TRIPATHI. P.C. 1988. "Personnel Management, Industrial Relations", New Delhi, Sultan Chan and Sons Publications.

GUPTA. C.B. 2005. "Business Organization and Management", New Delhi, Sultan Chan and Sons, Publications.

SUBBARAO. P. 1996. "Essential of Human Resource Management and Industrial Relations" Mumbai, Himalya Publishing House.

KOTHARI C.R. 1999. "Research Methodology Methods and Techniques", New Delhi, Wishwaprakashan Publication.

\section{WEBSITES}

hltp : // wwwioe.org / joe / 1998 June / $/ b_{3}$. Html.

www.ed@joe.org. 